\title{
EIF2AK2 Gene
}

National Cancer Institute

\section{Source}

National Cancer Institute. EIF2AK2 Gene. NCI Thesaurus. Code C24696.

This gene plays a role in the negative regulation of protein synthesis. 